\title{
Pengaruh Penerapan Metode Bermain Balok Terhadap Kecerdasan Kognitif Anak
}

\author{
R. Wardathi Khuzaifah Risman \\ Email:wardathikhuraifah@gmail.com
}

\section{Zulkifli}

Email:rulkifli@gmail.com

\begin{abstract}
Based on the results of observations in the field of children's cognitive intelligence has not developed optimally so it is necessary to apply the method of playing the beam. This research aims to determine the effect of the application of the method of playing the beam to the cognitive intelligence of children group B in RA Taskim 1 Tampan Sub District Pekanbaru City. The subject of this research are teacher and children. With the object is the influence of the application of playing beam methods to cognitive intelligence of group $B$. The population of this research are 29 children, and this sample of this research were children group $B$ who divided into two classes the namely control class for class B1 with 10 children and experiment class for class B2 with 10 children. Interpretation this sample by Purposive Sampling technic is mean determining technic sample with certain consideration. The data collection techniques used are test, observation, and documentation. Technique of data analysis using t-test test by using program of SPSS Windows ver.17. The research hypothesis is there is a significant influence between the application of the method of playing the beam to the child's cognitive intelligence. This can be known from the data analysis on pretest and posttest comparison of experimental class obtained thitung $=46,819$ and Sig. (2-tailed) $=0.000$. Because Sig. (2tailed $)=0.000<0,05$ it can be concluded that there is a significant influence after using the beam play method in learning. So it means $\mathrm{Ho}$ is rejected and Ha accepted meaning in this research there is influence of application of play method of beam before and after to cognitive intelligence of child residing in experiment class. The influence of the application of the method of playing block to the cognitive intelligence of group B's children in $\mathrm{R} A$ Taskim 1 Tampan District Pekanbaru City was $88.78 \%$.
\end{abstract}

Keywords : Cognitive Intelligence, Playing Beam

\begin{abstract}
Abstrak
Berdasarkan hasil pengamatan di lapangan terhadap kecerdasan kognitif anak yang belum berkembang dengan optimal sehingga perlu dilakukan penerapan metode bermain balok. Penelitian ini bertujuan untuk mengetahui pengaruh penerapan metode bermain balok terhadap kecerdasan kognitif anak kelompok B di RA Taskim 1 Kecamatan Tampan Kota Pekanbaru. Subjek penelitian ini adalah guru dan anak dengan objeknya pengaruh penerapan metode bermain
\end{abstract}


balok terhadap kecerdasan kognitif anak kelompok B. Populasi penelitian ini berjumlah 29 orang anak, sedangkan sampel penelitian ini adalah anak kelompok B yang terdiri dari dua kelas yaitu B1 berjumlah 10 orang anak sebagai kelas kontrol dan B2 berjumlah 10 orang anak sebagai kelas eksperimen. Pengambilan sampel dilakukan dengan teknik Purposive Sampling yang artinya adalah teknik penentuan sampel dengan pertimbangan tertentu. Adapun teknik pengumpulan data yang digunakan yaitu tes, observasi, dan dokumentasi. Teknik analisis data menggunakan uji t-test dengan menggunakan program SPSS Windows ver.17. Hipotesis penelitian adalah ada pengaruh yang signifikan antara penerapan metode bermain balok terhadap kecerdasan kognitif anak. Hal ini dapat diketahui dari hasil analisis data pada perbandingan pretest dan posttest kelas eksperimen yang diperoleh $t_{\text {hitung }}=46,819$ dan Sig. (2tailed $)=0.000$. Karena Sig. $(2$-tailed $)=0.000<0,05$ maka dapat disimpulkan bahwa terdapat pengaruh yang signifikan setelah menggunakan metode bermain balok dalam pembelajaran. Jadi artinya Ho ditolak dan Ha diterima yang berarti dalam penelitian ini terdapat pengaruh penerapan metode bermain balok sebelum dan sesudah terhadap kecerdasan kognitif anak yang berada pada kelas eksperimen. Pengaruh penerapan metode bermain balok terhadap kecerdasan kognitif anak kelompok B di RA Taskim 1 Kecamatan Tampan Kota Pekanbaru sebesar 88,78\%.

\section{Kata Kunci : Kecerdasan Kognitif, Bermain Balok}

\section{PENDAHULUAN}

Undang-undang Nomor 20 Tahun 2003 tentang Sistem Pendidikan Nasional Pasal 1 angka 14 menyatakan bahwa Pendidikan Anak Usia Dini (PAUD) adalah suatu upaya pembinaan yang ditujukan kepada anak sejak lahir sampai dengan usia enam tahun yang dilakukan melalui pemberian rangsangan pendidikan untuk membantu pertumbuhan dan perkembangan jasmani dan rohani agar anak memiliki kesiapan dalam memasuki pendidikan lebih lanjut.

Pendidikan Taman Kanak-Kanak merupakan salah satu lembaga pendidikan formal yang memberikan pelayanan pendidikan untuk usia 4 sampai 6 tahun. Sedangkan tugas utama seorang pendidik RA adalah memberikan stimulasi dan rangsangan bagi anak untuk mengoptimalkan fungsi organ-organ dalam tubuh yang akan mempengaruhi pertumbuhan dan perkembangan di masa mendatang.

Anak usia dini adalah sosok individu yang sedang menjalani suatu proses perkembangan dengan pesat dan sangat fundamental bagi kehidupan selanjutnya. Ia memiliki dunia dan karakteristik sendiri yang jauh berbeda dari orang dewasa. Anak selalu aktif, dinamis, antusias, dan ingin tahu terhadap apa yang dilihat dan didengarnya, seolah-olah tidak pernah berhenti belajar. Anak juga bersifat egosentris, memiliki rasa ingin tahu secara alamiah, merupakan makhluk sosial, unik, kaya dengan fantasi, memiliki daya perhatian yang pendek, dan merupakan masa yang paling potensial untuk belajar.

Proses pembelajaran anak usia dini, khususnya Raudhatul Athfal telah menjadi permasalahan yang disebabkan oleh pola pembelajaran yang dilaksanakan cenderung 
berorientasi akademik yaitu pembelajaran yang lebih menekankan pada pencapaian kemampuan anak dalam membaca, menulis, dan berhitung. Padahal pembelajaran yang dilakukan pada anak usia dini adalah untuk mengembangkan berbagai potensi pada anak seperti perkembangan kognitif, fisik motorik (kasar dan halus), bahasa, sosial emosional, serta nilai-nilai agama dan moral.

Dalam kaitannya dengan perkembangan potensi anak, Piaget menyatakan bahwa sejak lahir sampai dengan usia dua tahun, tingkat kemampuan berfikir anak baru mencapai tahap sensori-motor. Pada tahap ini anak berinteraksi dengan lingkungannya melalui alat-alat sensorinya, ia akan mempelajari segala sesuatu yang ada disekitar dia melalui penglihatan, pendengaran, penciuman, dan perabaan. Selanjutnya pada usia dua sampai tujuh tahun, tingkat kemampuan berfikir anak berada pada tahap pra-operasional konkret. Pada tahap ini proses berfikir anak terjadi melalui pengalaman langsung terhadap lingkungannya. Dengan pengalaman nyata memungkinkan anak untuk menunjukkan aktivitas dan rasa ingin tahu (curiousity) secara optimal, segala sesuatu yang dipahami oleh anak dimulai dari objek nyata.

Bermain merupakan suatu kegiatan yang melekat pada dunia anak. Bermain adalah kodrat anak. Pada intinya, "bermain dapat dipandang sebagai suatu kegiatan yang bersifat volunter, spontan, terfokus pada proses, memberi ganjaran secara intrinsik, menyenangkan dan fleksibel".

Adanya alat permainan edukatif, maka dapat meningkatkan motivasi peserta didik untuk belajar. Anak didik dapat mengulangi pelajaran yang telah diberikan dan dapat merangsang peserta didik untuk belajar dengan penuh semangat. Di samping itu, alat permainan edukatif dalam pengembangan kognitif anak dapat menarik minat peserta didik terhadap materi yang disajikan. Salah satu jenis dari bahan main adalah balok. Balok adalah potongan-potongan kayu yang polos (tanpa dicat) sama tebalnya dan dengan panjang dua kali atau empat kali sama besarnya dengan satu unit balok.

Dari pernyataan di atas, kita mengakui bahwa melalui kegiatan bermain berbagai kompetensi bidang pengembangan dapat diperoleh khususnya untuk anak usia dini. Kompetensi tersebut merupakan dasar pengembangan potensi anak kelak dikemudian hari. Guru sebagai kreator, pemimpin dan pembimbing permainan di lembaga RA harus jeli dan kreatif mengoptimalkan permainan di sekolah agar bidang pengembangan dan kecerdasan anak dapat dioptimalkan.

Untuk itu maka peneliti mencoba untuk melakukan penelitian mengenai adakah penerapan metode bermain balok berpengaruh terhadap kecerdasan kognitif anak. Tujuan penelitian ini bermaksud untuk mengetahui ada atau tidaknya pengaruh penerapan bermain balok terhadap kecerdasan kognitif anak.

\section{METODE}

\section{Jenis Penelitian}

Penelitian ini merupakan penelitian kuantitatif dengan metode eksperimen. Apabila penelitian bertujuan meramalkan dan menjelaskan hal-hal yang terjadi diantara variabel-variabel tertentu melalui upaya manipulasi atau 
pengontrolan variabel-variabel tersebut atau hubungan diantara mereka, agar ditemukan hubungan, pengaruh, atau perbedaan salah satu atau lebih variabel, maka penelitian yang demikian disebut penelitian eksperimen. Metode penelitian eksperimen merupakan metode penelitian yang digunakan untuk mencari pengaruh treatment (perlakuan tertentu). Prosedur penelitian dimulai dari tahap penyusunan rencana perlakuan, observasi awal, pelaksanaan perlakuan, dan observasi akhir. Instrument yang digunakan untuk menilai kecerdasan kognitif anak berupa tanda check list $(\sqrt{ })$ pada kategori belum berkembang sampai dengan berkembang sangat baik.

Penelitian eksperimen dapat diartikan sebagai metode penelitian yang digunakan untuk mencari pengaruh perlakuan tertentu terhadap yang lain dalam kondisi yang terkendali. Rancangan penelitian yang digunakan adalah dengan menggunakan rancangan penelitian model pra eksperimen pretest-posttest control group design yaitu eksperimen yang dilakukan pada dua kelompok dengan menggunakan kelas pembanding. Model desain ini dapat digambarkan sebagai berikut :

Tabel III.1 Pretest-Posttest Control Group Design

\begin{tabular}{ccc}
\hline Pretest & Treatment & Posttest \\
\hline $\mathrm{A}_{1}$ & $\mathrm{X}$ & $\mathrm{A}_{2}$ \\
$\mathrm{~A}_{3}$ & - & $\mathrm{A}_{4}$ \\
\hline
\end{tabular}

Keterangan :

$\mathrm{A}_{1}$ : Nilai pretest kelas eksperimen sebelum diberi perlakuan.

$\mathrm{X}$ : Perlakuan.

$\mathrm{A}_{2}$ : Nilai posttest kelas eksperimen sesudah diberikan perlakuan.

$\mathrm{A}_{3}$ : Nilai pretest kelas kontrol tanpa perlakuan.

$\mathrm{A}_{4}$ : Nilai posttest kelas kontrol tanpa perlakuan.

\section{Tempat dan Waktu Penelitian}

Tempat penelitian ini adalah di RA Taskim 1 Kecamatan Tampan Kota Pekanbaru di Jl. Suka Karya Gg. Rukun No. 88 J Kualu Panam dan waktu penelitiannya dilaksanakan pada Bulan November 2017 - Januari 2018.

\section{Subjek dan Objek Penelitian}

Subjek dalam penelitian ini adalah guru dan anak di RA Taskim 1 Kecamatan Tampan Kota Pekanbaru, sedangkan yang menjadi objek penelitian adalah pengaruh penerapan metode bermain balok terhadap kecerdasan kognitif anak Kelompok B di RA Taskim 1 Kecamatan Tampan Kota Pekanbaru.

\section{Populasi dan Sampel Penelitian}

Populasi adalah seluruh data yang menjadi perhatian peneliti dalam suatu ruang lingkup, dan waktu yang sudah ditentukan. Dalam penelitian ini ditentukan subjek sebagai sumber data yang relevan dengan masalah yang diteliti untuk dipelajari dan ditarik kesimpulannya. Sampel merupakan populasi atau subjek yang dipilih dan ditetapkan sebagai sumber data atau sumber informasi 
dari penelitian. Pengambilan sampel dilakukan dengan teknik Purposive Sampling yang artinya adalah teknik penentuan sampel dengan pertimbangan tertentu.

Populasi penelitian ini berjumlah 29 orang anak di RA Taskim 1 Kecamatan Tampan Kota Pekanbaru. Sampel dalam penelitian ini adalah anak kelompok B di RA Taskim 1 Kecamatan Tampan Kota Pekanbaru, yang terdiri dari dua kelas yaitu B1 berjumlah 10 orang anak sebagai kelas kontrol dan B2 berjumlah 10 orang anak sebagai kelas eksperimen.

\section{Data dan Instrumen}

Data yang digunakan dalam penelitian ini adalah data primer yaitu data yang diambil langsung oleh responden. Instrumen yang digunakan dalam penelitian ini adalah Lembar Kerja Anak (LKA).

\section{Teknik Pengumpulan Data}

a. Tes

Dalam tes ini yang peneliti lakukan adalah memberikan beberapa kali uji coba sesuai dengan kemampuan berpikir anak serta sesuai tingkat umur anak tentunya tidak memberikan soal, melainkan dengan memberikan tugas berbentuk LKA (Lembar Kerja Anak).

b. Observasi

Dalam penelitian ini, observasi digunakan untuk mengumpulkan data tentang kecerdasan kognitif anak sebelum dan sesudah diberikan perlakuan dengan bermain balok.

c. Dokumentasi

Dokumentasi merupakan suatu teknik pengumpulan data dengan cara melakukan pencatatan dan pengambilan gambar maupun rekaman terhadap objek yang diteliti. Dokumentasi dilakukan untuk mengumpulkan data tentang kegiatan pembelajaran melalui foto.

\section{Teknik Analisis Data}

Teknik analisis data yang digunakan pada penelitian ini adalah teknik analisis uji-t. Untuk melihat apakah ada pengaruh penerapan metode bermain balok terhadap kecerdasan kognitif anak sebelum dan sesudah diberi perlakuan. Adapun proses dalam analisis data ini menggunakan rumus uji-t digunakan untuk menguji signifikan perbedaan mean.

\section{HASIL DAN PEMBAHASAN}

Untuk mengetahui seberapa besar pengaruh penerapan metode bermain balok terhadap kecerdasan kognitif anak di RA Taskim 1 Kecamatan Tampan Kota Pekanbaru.

Berdasarkan hasil didapat bahwa pengaruh yang diberikan penerapan metode bermain balok terhadap kecerdasan kognitif anak di RA Taskim 1 Kecamatan Tampan Kota Pekanbaru adalah sebesar 88,78\%. Terdapat 3 kategori perolehan skor gain ternormalisasi yaitu: 
Tabel IV.9 Kategori Gain Ternormalisasi

\begin{tabular}{cc}
\hline \multicolumn{2}{c}{ Gain Ternormalisasi } \\
\hline Gain Ternormalisasi & Kriteria Penilaian \\
$\mathrm{G}<30$ & Rendah \\
$30 \%<\mathrm{G}<70 \%$ & Sedang \\
$\mathrm{G}>70 \%$ & Tinggi \\
\hline
\end{tabular}

Merujuk pada hasil penggunaan rumus $G$ di atas, maka dapat dilihat kategori peningkatan sebesar 88,78\% yaitu berada pada kategori tinggi 88,78\%>70\%.

Bermain balok dapat memberikan dorongan kepada anak untuk belajar dengan baik dan tertib. Belajar dengan memperhatikan bentuk yang berbeda-beda, khususnya dalam mengembangkan kognitif anak. Dengan demikian anak akan lebih bersemangat dan tidak bosan, bahkan anak akan senang menceritakan bentuk dan bangunan yang berbeda-beda yang telah diciptakan oleh anak. Adanya pengetahuan mengembangkan kognitif akan lebih mudah bagi orang dewasa lainnya dalam menstimulasi kemampuan kognitif anak sehingga akan tercapai optimalisasi potensi pada masing-masing anak.

Berdasarkan analisis pengeloaan data dan hasil presentasi di atas dapat dilihat hasil pretest kecerdasan kognitif anak di RA Taskim 1 Kecamatan Tampan Kota Pekanbaru diperoleh jumlah nilai 76 dengan rata-rata 27,14\% pada kelas kontrol dan 75 dengan rata-rata 26,78\% pada kelas eksperimen. Jika dilihat dari kriteria perorangan, tidak ada anak yang berada pada kriteria Berkembang Sangat Baik (BSB), Berkembang Sesuai Harapan (BSH), Mulai Berkembang (MB) atau 0\% pada kedua kelas baik kelas eksperimen maupun kelas kontrol, yang berada pada Belum Berkembang (BB) sebanyak 10 orang anak atau 100\% pada kelas kontrol dan pada kelas eksperimen.

Berdasarkan data di atas artinya kecerdasan kognitif anak pada anak saat pretest masih rendah. Terbukti saat proses pembelajaran, peneliti melakukan pengamatan kepada anak secara langsung dan dapat dilihat kecerdasan kognitif anak di RA Taskim 1 Kecamatan Tampan Kota Pekanbaru masih rendah, dimana anak masih belum bisa memecahkan masalah sederhana dalam kehidupan sehari-hari dengan cara yang fleksibel, menerapkan pengetahuan dalam konteks yang baru, mengenal berbagai perbedaan bentuk benda, mengklasifikasikan bentuk-bentuk geometri seperti segitiga, lingkaran, dan persegi, berfikiran simbolik dalam menentukan bentuk benda yang sama, merepresentasikan berbagai bentuk dalam bentuk gambar, dan memasang benda sesuai dengan pasangannya.

Ini menandakan bahwa metode yang sering digunakan guru untuk mengembangkan kecerdasan kognitif anak di RA Taskim 1 Kecamatan Tampan Kota Pekanbaru ternyata anak masih belum menguasai permainan balok, ini terlihat guru masih menggunakan alat permainan balok yang tidak menarik perhatian anak. Sebagian anak masih belum bisa mengklasifikasikan warna, bentuk, dan ukuran balok.

Rendahnya kecerdasan kognitif anak disebabkan oleh media atau permainan yang kurang menarik saat pembelajaran sehingga membuat anak kurang bersemangat mengikuti pembelajaran dan anak tidak dapat mengikuti pembelajaran dengan serius. Berdasarkan hasil yang telah dicapai pada pretest maka perlu dilakukan 
peningkatan kecerdasan kognitif anak melalui treatment dengan mengunakan penerapan metode bermain balok.

Setelah pemberian treatment, anak memperlihatkan antusiasme ketika melakukan kegiatan mengerjakan Lembar Kerja Anak (LKA). Bahkan ada anak yang sudah bisa memasang benda sesuai dengan pasangannya tanpa bantuan guru lagi. Guru hanya mengarahkan anak diawal kegiatan saja. Setelah anak menggunakan metode bermain balok dilakukan evaluasi terhadap kecerdasan kognitif anak.

Berikut paparan datanya setelah dilakukan posttest diperolehlah jumlah nilai 151 dengan nilai rata-rata 53,92\% pada kelas kontrol dan kelas eksperimen 257 dengan rata-rata $91,78 \%$. Peningkatan nilai rata-rata pada kelas eksperimen sangat terlihat pada saat pretest, rata-ratanya adalah $26,78 \%$ dan meningkat pada saat posttest menjadi $91,78 \%$ setelah menggunakan penerapan metode bermain balok. Ini terlihat bahwa pada kelas kontrol peningkatan tidak terlalu tinggi sedangkan pada kelas eksperimen terjadi peningkatan yang cukup tinggi. Pada kelas kontrol tidak terlalu tinggi karena hanya melakukan kegiatan seperti biasa tanpa memberikan perlakuan. Jika dilihat secara perorangan sesudah diberi treatment pada kelas eksperimen maka berada pada kriteria Berkembang Sangat Baik (BSB) sebanyak 10 orang atau 100\%, dan tidak ada anak yang berada pada kriteria Berkembang Sesuai Harapan (BSH), Mulai Berkembang (MB) dan Belum Berkembang (BB).

Berdasarkan posttest yang dilakukan peneliti dapat dilihat pada proses pembelajaran bahwa anak sudah mampu memecahkan masalah sederhana dalam kehidupan sehari-hari dengan cara yang fleksibel, menerapkan pengetahuan dalam konteks yang baru, mengenal berbagai perbedaan bentuk benda, mengklasifikasikan bentuk-bentuk geometri seperti segitiga, lingkaran, dan persegi, berfikiran simbolik dalam menentukan bentuk benda yang sama, merepresentasikan berbagai bentuk dalam bentuk gambar, dan memasang benda sesuai dengan pasangannya.

\section{Gambar dan Tabel}

Tabel IV.7 Rekapitulasi kecerdasan kognitif anak sebelum dan sesudah diberikan metode bermain balok di RA Taskim 1 Kecamatan Tampan Kota Pekanbaru pada kelas eksperimen

\begin{tabular}{clccccc}
\hline \multirow{2}{*}{ No } & \multirow{2}{*}{ Kategori } & \multirow{2}{*}{$\begin{array}{c}\text { Rentang } \\
\text { Skor }\end{array}$} & \multicolumn{2}{c}{ Eksperimen } & \multicolumn{2}{c}{ Kontrol } \\
\cline { 3 - 7 } & & F & $\%$ & F & $\%$ \\
\hline 1 & Berkembang Sangat Baik & $76-100 \%$ & 0 & 0 & 10 & 100 \\
2 & Berkembang Sesuai Harapan & $56-75 \%$ & 0 & 0 & 0 & 0 \\
3 & Mulai Berkembang & $41-55 \%$ & 0 & 0 & 0 & 0 \\
4 & Belum Berkembang & $<40 \%$ & 10 & 100 & 0 & 0 \\
& Jumlah & & 10 & 100 & 10 & 100 \\
\hline
\end{tabular}

Sumber: Rekapitulasi kecerdasan kognitif anak. 
Tabel IV.8 Rekapitulasi kecerdasan kognitif anak sebelum dan sesudah diberikan tanpa metode bermain balok di RA Taskim 1 Kecamatan Tampan Kota Pekanbaru pada kelas kontrol

\begin{tabular}{clccccc}
\hline \multirow{2}{*}{ No } & \multirow{2}{*}{ Kategori } & \multirow{2}{*}{$\begin{array}{c}\text { Rentang } \\
\text { Skor }\end{array}$} & \multicolumn{2}{c}{ Eksperimen } & \multicolumn{2}{c}{ Kontrol } \\
\cline { 4 - 7 } & & F & $\%$ & F & $\%$ \\
\hline 1 & Berkembang Sangat Baik & $76-100 \%$ & 0 & 0 & 0 & 0 \\
2 & Berkembang Sesuai Harapan & $56-75 \%$ & 0 & 0 & 3 & 30 \\
3 & Mulai Berkembang & $41-55 \%$ & 0 & 0 & 7 & 70 \\
4 & Belum Berkembang & $<40 \%$ & 10 & 100 & 0 & 0 \\
& Jumlah & & 10 & 100 & 10 & 100 \\
\hline
\end{tabular}

Sumber: Rekapitulasi kecerdasan kognitif anak.

\section{KESIMPULAN}

Berdasarkan hasil penelitian yang dilakukan di RA Taskim 1 Kecamatan Tampan Kota Pekanbaru bahwa data pada perbandingan pretest dan posttest kelas eksperimen dengan menggunakan uji-t maka diperoleh thitung $=46,819$ dan Sig. (2tailed $)=0.000$. Karena Sig. (2-tailed) $=0.000<0,05$ maka dapat disimpulkan bahwa terdapat pengaruh yang signifikan setelah menggunakan metode bermain balok dalam pembelajaran. Jadi artinya Ho ditolak dan Ha diterima yang berarti dalam penelitian ini terdapat pengaruh penerapan metode bermain balok sebelum dan sesudah terhadap kecerdasan kognitif anak yang berada pada kelas eksperimen. Pengaruh penerapan metode bermain balok terhadap kecerdasan kognitif anak kelompok B di RA Taskim 1 Kecamatan Tampan Kota Pekanbaru sebesar $88,78 \%$.

\section{DAFTAR PUSTAKA}

Aliyy, Al. (1995). Al-Qur'an dan Terjemahnya. Jawa Barat: CV. Penerbit Diponegoro.

Arikunto, Suharsimi. (2016). Manajemen Penelitian. Jakarta : PT. Rineka Cipta.

Bungin, Burhan. (2005). Metodologi Penelitian Kuantitaif (Komunikasi, Ekonomi, dan Kebijakan Publik serta Ilmu-Ilmu Sosial Lainnya). Jakarta : Penerbit Kencana Prenadamedia Group.

Coughlin, Pamela A. (2010). Menciptakan Kelas yang Berpusat pada Anak 3-5 Tabun. Washington : Children Resources Internasional.

Desmita. (2010). Psikologi Perkembangan Peserta Didik. Bandung : PT. Remaja Rosdakarya Offset.

E-Journal PG PAUD Universitas Pendidikan Ganesha Jurusan Pendidikan Guru Pendidikan Anak Usia Dini (Volume 2 No. 1 Tahun 2014).

Hartati, Sofia. (2005). Perkembangan Anak Usia Dini. Jakarta : Depdiknas.

Kasmadi, Nia Siti Sunariah. (2014). Panduan Modern Penelitian Kuantitatif. Bandung : CV. Alfabeta. 
Latif, Mukhtar dkk. (2013). Orientasi Baru Pendidikan Anak Usia Dini Teori dan Aplikasi. Jakarta : Kencana Prenada Media Group.

Lili Suryani, (2017). Kepala Sekolah RA Taskim 1 Kecamatan Tampan Kota Pekanbaru, Pekanbaru: Wawancara pukul 09.00 WIB.

Masitoh. (2007). Strategi Pembelajaran TK. Cetakan Keenam. Jakarta : Universitas Terbuka.

Moeslichatoen. (2004). Metode Pengajaran di Taman Kanak-Kanak. Cetakan Kedua. Jakarta : Departemen Pendidikan \& Kebudayaan, Rineka Cipta.

Musfiroh, Tadkiroatun. (2005). Bermain Sambil Belajar dan Mengasah Kecerdasan (Stimulasi Multiple Intelligences Anak Usia Taman Kanak-Kanak). Jakarta : Departemen Pendidikan Nasional.

Noor, Juliansyah. (2012). Metodologi Penelitian. Jakarta : Kencana Pernada Media Group.

Nurgiyantoro, Burhan dkk. (2015). Statistik Terapan untuk Penelitian Ilmu Sosial. Yogyakarta : Gadjah Mada University Press.

Patmonodewo, Soemiarti. (2000). Pendidikan Anak Prasekolah. Cetakan Pertama. Jakarta: Departemen Pendidikan dan Kebudayaan \& PT. Rineka Cipta.

Peraturan Menteri Pendidikan Nasional Republik Indonesia Nomor 58 Tahun 2009 tentang Standar Pendidikan Anak Usia Dini.

Prasojo, Suminaring. (2010). Permainan Angka dan Logika (Aneka Aktivitas untuk Meningkatkan Kecerdasan Anak Usia 3-5 Tabun (PAUD]). Yogyakarta : Penerbit Diva Press.

Sari Widyastuti, Diah. (2015). Permainan Balok Berpengaruh Terbadap Kemampuan Kognitif Anak (Penelitian Pada Kelompok B TK Pertiwi Mlese Kabupaten Klaten Tabun Ajaran 2014/2015). Surakarta: Skripsi Mahasiswi Universitas Muhammadiyah.

Sugiyono. (2011). Metode Penelitian Kuantitatif, Kualitatif, dan R\&D. Bandung : Penerbit Alfabeta.

Sugiyono. (2013). Metode Penelitian Kuantitatif, Kualitatif, dan R\&D. Bandung : Penerbit Alfabeta.

Sujiono, Yuliani Nurani dkk. (2005). Metode Pengembangan Kognitif. Cetakan Kedua. Jakarta : Universtas Terbuka.

Susanti, Yessi. (2012). Pengembangan Kognitif Anak Usia 4-5 Tahun Melalui Bermain Balok di TK Nurul Islam Muaro Sentajo. Pekanbaru : Skripsi Mahasiswi STKIP Aisyiyah Riau.

Syah, Muhibbin. (2014). Telaab Singkat Perkembangan Didik. Cetakan Kesatu. Jakarta : PT. Rajagrafindo Persada.

Triharso, Agung. (2013). Permainan Kreatif \& Edukatif untuk Anak Usia Dini. Yogyakarta : Penerbit Andi (CV. Andi Offset). 
Pengarub Penerapan Metode Bermain Balok Terhadap Kecerdasan Kognitif Anak

Umama. (2007). Checklist Indikator Perkembangan Anak 0-6 Tabun. Rumah Inspirasi : Pusat Kurikulum Diknas. 